\title{
Pengaruh Substitusi Tepung Beras Hitam (Oryza Sativa $L$. Indica) Pada Pembuatan Roti Tawar Terhadap Daya Terima Konsumen
}

\author{
Dwi Meliana Putri 1),b), Guspri Devi Artanti ${ }^{2), b)}$, dan Sachriani ${ }^{3), c)}$ \\ 1,2,3 Program Studi Pendidikan Tata Boga, Universitas Negeri Jakarta, Jalan Rawamangun Muka, \\ DKI Jakarta, 13220 \\ e-mail: melianaputridwi@gmail.com ${ }^{\text {a)}}$,vie_artanti@yahoo.com ${ }^{\text {b) }}{ }^{\text {, sachrianisachrom@ gmail.com }}{ }^{\text {c) }}$
}

\begin{abstract}
The objective of this study was to learn the effect of black rice flour substitution on white bread processing to consumer acceptance, covering aspects of external (volume and skin color), and aspects of internal (skin character, crumb color, flavor, taste and texture). This study used an experimental method performed at the Laboratory of Pastry and Bakery, Food and Nutrition Program, Faculty of Technology, State University of Jakarta from January until December 2020. Organolaptic test conducted on 25 no trained panelists. The results of the descriptive data showed that white bread substitute black rice flour as much as $10 \%$ are most preferred by consumers in all aspects, with an average of 4.52 aspects of volume; outer aspect of color 4.24; aspects of the crumb of 4.16; aspects of the crumb color of 4.12; aroma aspects of 4.32; flavor aspects of 4.4; and crumb texture aspects of 4.48 which all aspects a showed that are in the range of categories like to very like. Hypothesis analyze using Friedman test showed that there is a substitution effect of black rice flour on white bread processing in percentage $10 \%, 20 \%$, and $30 \%$ on consumer acceptance on all aspects: volume, the color of the skin or crust, crumb / pores, crumb color, flavor, taste, and texture. Tuckeys test results showed that white bread substitute black rice flour in percentage $10 \%$ dan $20 \%$ are the preferred consumer, with the recommended substitution formula as much as $20 \%$ as the best usage of the black rice.
\end{abstract}

Keys Word: White Bread, Black Rice Flour, To Consumer Acceptance

\begin{abstract}
Abstrak
Penelitian ini bertujuan untuk mempelajari pengaruh substitusi tepung beras hitam pada pembuatan roti tawar terhadap daya terima konsumen yang meliputi aspek eksternal (volume dan warna kulit luar), aspek internal (remah / pori-pori, warna remah, aroma, rasa dan tekstur. Penelitian ini menggunakan metode eksperimen yang dilakukan di Laboratorium Pastry dan Bakery, Program Studi Tata Boga, Fakultas Teknik, Universitas Negeri Jakarta pada bulan Januari hingga Desember 2020. Uji organoleptik dilakukan pada 25 orang panelis tidak terlatih. Hasil dari deskriptif data menunjukkan bahwa roti tawar substitusi tepung beras hitam sebanyak $10 \%$ adalah yang paling disukai oleh konsumen pada semua aspek, dengan rata-rata untuk aspek volume 4,52; aspek warna bagian luar 4,24; aspek remah/ pori-pori 4,16; aspek warna remah 4,12; aspek aroma 4,32; aspek rasa 4,40 dan aspek tekstur 4,48 dimana pada semua aspek menunjukkan berada pada rentangan kategori suka hingga sangat suka. Hasil pengujian hipotesis menggunakan uji Friedman menunjukkan bahwa terdapat pengaruh substitusi tepung beras hitam pada pembuatan roti tawar dengan persentase $10 \%, 20 \%$, dan $30 \%$ terhadap daya terima panelis pada semua aspek yaitu aspek volume, warna bagian luar atau kerak, remah/poripori, warna remah, aroma, rasa, dan tekstur. Hasil uji Tuckeys menunjukkan bahwa roti tawar substitusi tepung beras hitam dengan persentase $10 \%$ dan $20 \%$ adalah yang disukai konsumen, dengan formula yang disarankan substitusi sebesar $20 \%$ sebagai optimalisasi pemanfaatan beras hitam.
\end{abstract}

Kata kunci: Roti Tawar, Tepung Beras Hitam, Daya Terima Konsumen 


\section{PENDAHULUAN}

Pada era globalisasi dengan tingkat kesibukan masyarakat yang padat dan mobilitas yang tinggi membuat masyarakat perkotaan membutuhkan suatu makanan yang cepat dan mudah didapatkan untuk dikonsumsi demi mendukung rutinitas sehari-hari. Roti dapat dikatakan sudah menjadi gaya hidup masyarakat perkotaan, karena makanan ini mudah didapatkan dan sering kali dikonsumsi sebagai menu alternatif sumber karbohidrat pengganti nasi. Roti merupakan produk pangan berbahan dasar tepung terigu yang di fermentasi dengan ragi atau bahan pengembang lainnya yang diolah dengan cara dipanggang (Mudjajanto dan Yulianti, 2010).

Roti tawar merupakan jenis roti yang banyak dikonsumsi oleh masyarakat Indonesia. Menurut Data Statistik Konsumsi Pangan (2018), konsumsi roti tawar pada tahun 2018 mencapai 19.085 bungkus, sedangkan pada tahun 2014 sebesar 3.244 bungkus. Berdasarkan data tersebut, dapat diketahui bahwa kebutuhan roti tawar mengalami peningkatan dari tahun ke tahun yang menyebabkan roti tawar memiliki banyak variasi dari segi rasa maupun bahan yang digunakan sehingga menghasilkan nilai gizi yang berbeda. Hal ini tentunya merupakan potensi untuk mengembangkan produk roti tawar dengan kandungan serat yang tinggi dengan memanfaatkan sumber karbohidrat yang ada di Indonesia. Sumber karbohidrat berserat tinggi yang mulai diminati oleh masyarakat adalah beras hitam.

Beras hitam (Oryza sativa L. Indica) merupakan jenis beras yang berwarna hitam karena aleuron dan endospermanya memproduksi antosianin dengan intensitas tinggi sehingga berwarna ungu pekat mendekati warna hitam. Kandungan antosianin dalam beras hitam sebesar $66.27 \%$ (Aziz, dkk. 2015). Antosianin memiliki beberapa manfaat bagi tubuh, diantaranya sebagai antioksidan yang dapat mencegah penyakit kanker, membantu menjaga kadar kolesterol dalam darah, membantu mengeluarkan zat beracun dari tubuh, dan mencegah pengerasan pembuluh nadi (Kristamtini, 2014). Selain itu, beras hitam memiliki kandungan serat pangan (dietary fiber), vitamin, mikroelemen, dan asam amino yang cukup tinggi. Hasil penelitian Utama (2019) menunjukkan beras hitam mengandung serat pangan (dietary fiber) sebesar 7,5\%, dan hemiselulosa 5,8\%. Serat pangan berfungsi untuk pemeliharaan kesehatan dan mencegah terserangnya berbagai penyakit (Astawan, 2004). Beras hitam juga memiliki indeks glikemik rendah yang berguna untuk menjaga kestabilan gula darah sehingga aman apabila dikonsumsi oleh penderita diabetes sebagai menu diet. Salah satu bentuk pengolahan beras hitam yaitu dengan membuat tepung. Pengolahan bahan menjadi tepung memiliki keuntungan, yaitu memperpanjang umur simpan dan mudah diaplikasikan ke berbagai produk makanan sehingga dapat meningkatkan nilai gizi dari produk yang dihasilkan (Suryana, Dayat 2013).

Pemanfaatan tepung beras hitam dalam pembuatan produk pangan yang dapat meningkatkan nilai gizi, dapat dilihat pada penelitian Wijayanti (2018), mengenai pengaruh penggunaan tepung beras hitam dalam peningkatan kualitas butter cookies menghasilkan butter cookies dengan kandungan gizi karbohidrat $41,9 \%$, protein $7,82 \%$, dan serat $1,32 \%$ yang didapatkan dari substitusi tepung beras hitam sebesar 25\%. Hasil penelitian Hidayat, dkk (2019) juga menunjukkan bahwa pengunaan $10 \%$ tepung beras hitam menghasilkan produk bakpao dengan kandungan gizi karbohidrat sebesar $48,15 \%$, protein $7,46 \%$, lemak $6,10 \%$, air $37,44 \%$, abu $0,85 \%$, serat kasar $2,42 \%, I C_{50}$ $41,48 \%$, dan daya kembang $52,41 \%$ dari 100gram bakpao.

Selain meningkatkan nilai gizi, pengunaan tepung beras hitam juga dapat menghasilkan suatu produk dengan mutu organoleptik variasi baru yang disukai. mempengaruhi mutu organoleptik suatu produk yang disukai. Pada penelitian ini, tepung beras hitam digunakan sebagai bahan substitusi pada pembuatan roti tawar untuk menghasilkan roti tawar variasi baru dari segi warna, rasa, aroma serta tekstur, dan diharapkan dapat menambah nilai gizi roti tawar.

\section{METODE}

Penelitian ini menggunakan metode penelitian eksperimen. Pada penelitian ini dilakukan uji organoleptik hedonik untuk mengetahui pengaruh substitusi tepung beras hitam pada pembuatan roti tawar terhadap daya terima yang meliputi aspek volume, warna bagian luar, remah/pori-pori, warna bagian luar, aroma, rasa, dan tekstur dengan 3 (tiga) persentase substitusi tepung beras hitam yang 
berbeda yaitu $10 \%$, 20\%, dan $30 \%$. Responden pada penelitian ini adalah panelis tidak terlatih sebanyak 25 (dua puluh lima) panelis. Sebelumnya, dilakukan uji validasi yaitu uji organoleptik mutu hedonik terhadap 3 (tiga) panelis ahli yang meliputi 9 (sembilan) aspek penilaian, yaitu volume, warna bagian luar, karakter kulit, remah/pori-pori, warna bagian dalam, aroma, rasa, dan tekstur.

Pada proses pembuatan roti tawar substitusi tepung beras hitam bahan-bahan yang digunakan terdiri dari tepung terigu protein tinggi, tepung beras hitam, ragi instant, garam, gula pasir, bread improver, susu bubuk, air, dan shortening.

TABEL 1. Formula Roti Tawar Substitusi Tepung Beras Hitam

\begin{tabular}{lccc}
\hline \multirow{2}{*}{ Bahan } & \multicolumn{3}{c}{ Persentase Tepung Beras Hitam } \\
\cline { 2 - 4 } & $\mathbf{1 0 \%}$ & $\mathbf{2 0 \%}$ & $\mathbf{3 0 \%}$ \\
\hline Tepung Terigu Protein Tinggi & 450 & 400 & 350 \\
Tepung Beras Hitam & 50 & 100 & 150 \\
Ragi Instant & 5 & 5 & 5 \\
Garam & 8 & 8 & 8 \\
Gula Pasir & 40 & 40 & 40 \\
Bread Improver & 1 & 1 & 1 \\
Susu Bubuk & 25 & 25 & 25 \\
Air & 290 & 290 & 290 \\
Shortening & 30 & 30 & 30 \\
\hline
\end{tabular}

\section{HASIL DAN PEMBAHASAN}

Hasil data dalam penelitian diperoleh melalui dua tahap. Pada tahapan pertama yaitu uji validitas, uji ini berguna untuk mengukur kualitas dan kelayakan roti tawar substitusi tepung beras hitam, uji ini ditujukan kepada 3 orang panelis ahli. Pada tahap kedua, uji daya terima konsumen terhadap produk roti tawar substitusi tepung beras hitam yang ditujukan kepada 25 orang panelis tidak terlatih yaitu masyakarakat umum. Hasil penelitian ini meliputi hasil uji validitas, uji daya terima dan uji hipotesis menggunakan uji Friedman, jika uji hipotesis terdapat perbedaan pada salah satu perlakuan maka akan dilanjutkan pada uji Tuckey untuk mengetahui variasi kelompok yang paling disukai oleh panelis diantara kelompok-kelompok yang dianalisis.

Uji daya terima aspek yang dinilai meliputi aspek eksternal (volume dan warna bagian luar), dan aspek internal (remah atau pori-pori, warna bagian dalam, aroma, rasa dan tekstur remah) dengan rentang skala 5 sampai dengan 1, dari hasil tertinggi hingga terendah yaitu sangat suka, suka, agak suka, tidak suka, sangat tidak suka.

\section{Uji Validasi Roti Tawar Substitusi Tepung Beras Hitam}

Hasil uji validasi dapat dilihat pada tabel sebabagi berikut:

TABEL 2. Hasil Uji Validitas Panelis Ahli

\begin{tabular}{ccccccc}
\hline \multirow{2}{*}{ Aspek Penilaian } & \multirow{2}{*}{ Perlakuan } & P1 & P2 & P3 & Jumlah & Mean \\
\cline { 3 - 7 } Faktor Eksternal & & & & & & \\
\hline \multirow{2}{*}{ Volume } & $10 \%$ & 5 & 4 & 3 & 12 & 4 \\
& $20 \%$ & 5 & 5 & 5 & 15 & 5 \\
& $30 \%$ & 3 & 3 & 4 & 10 & 3.3 \\
\hline \multirow{2}{*}{ Warna bagian luar } & $10 \%$ & 5 & 5 & 2 & 12 & 4 \\
& $20 \%$ & 5 & 5 & 4 & 14 & 4.6 \\
\multirow{2}{*}{ Karakteristik Kulit } & $30 \%$ & 5 & 4 & 3 & 12 & 4 \\
\hline
\end{tabular}




\begin{tabular}{ccccccc}
\hline & $30 \%$ & 3 & 3 & 3 & 9 & 3 \\
\hline Faktor Internal & & & & & & \\
\hline \multirow{3}{*}{ Remah atau pori-pori } & $10 \%$ & 4 & 5 & 3 & 12 & 4 \\
& $20 \%$ & 5 & 5 & 5 & 15 & 5 \\
\hline \multirow{2}{*}{ Warna bagian dalam } & $30 \%$ & 3 & 2 & 4 & 9 & 3 \\
atau remahan & $10 \%$ & 5 & 3 & 3 & 11 & 3.6 \\
& $20 \%$ & 5 & 4 & 4 & 13 & 4.3 \\
Aroma & $30 \%$ & 5 & 5 & 4 & 14 & 4.6 \\
& $10 \%$ & 4 & 3 & 5 & 12 & 4 \\
Rasa & $20 \%$ & 3 & 3 & 3 & 9 & 3 \\
& $30 \%$ & 1 & 2 & 4 & 7 & 2.3 \\
\hline \multirow{2}{*}{ Tektur Remah } & $10 \%$ & 3 & 3 & 4 & 10 & 3.3 \\
& $20 \%$ & 3 & 3 & 3 & 9 & 3 \\
& $30 \%$ & 2 & 2 & 2 & 6 & 2 \\
\hline
\end{tabular}

Berdasarkan hasil validitas diatas roti tawar pada aspek volume dengan persentase substitusi tepung beras hitam $10 \%$ diperoleh nilai rata-rata 4 , yaitu berukuran agak besar. Sedangkan substitusi tepung beras hitam $20 \%$ dan $30 \%$ masing-masing memperoleh nilai rata-rata besar dan sedang. Kualitas terbaik roti tawar pada aspek volume ada pada roti tawar substitusi tepung beras hitam $20 \%$.

Hasil uji validasi kepada 3 panelis ahli terhadap aspek warna bagian luar roti tawar substitusi tepung beras hitam menunjukan pelakuan $10 \%$ dan $30 \%$ diperoleh nilai rata-rata 4 yang artinya warna bagian luar roti tawar berwarna merata sebagai kualitas pertama dari standard kualitas yang diharapkan peneliti, pada perlakuan $20 \%$ diperoleh nilai rata-rata 4.6 yang artinya warna bagian luar roti tawar berada pada rentang antara agak merata hingga merata. Pada aspek warna bagian luar roti tawar kualitas terbaik ada pada roti tawar substitusi tepung beras hitam $20 \%$.

Perolehan nilai rata-rata dari hasil uji validitas terhadap aspek karakteristik kulit roti tawar dengan substitusi tepung beras hitam menunjukan pelakuan 10\% sebesar 4 yang artinya karakteristik kulit pada roti tawar lembut sebagai kualitas kedua dari standar kualitas yang diharapkan peneliti. Pada perlakuan 20\% diperoleh nilai rata-rata sebesar 3.6 yang artinya karakteristik kulit roti tawar berada pada rentang mendekati lembut sebagai kualitas kedua dari standar kualitas yang diharapkan peneliti. Sedangkan pada perlakuan 30\% diperoleh nilai rata-rata 3 yang artinya roti tawar memiliki karakteristik kulit agak lembut sebagai kualitas ketiga dari standar kualitas yang diharapkan peneliti.

Aspek remah atau pori-pori pada roti tawar dengan persentase substitusi tepung beras hitam $10 \%$ dan 20\% masing-masing nilai rata-rata yang diperoleh 4 dan 5 yang artinya remah atau pori-pori kasar merata dan halus merata sebagai kualitas taraf kedua dan pertama dari standar yang ditetapkan. Pada perlakuan 30\% diperoleh nilai rata-rata sebesar 3 yang artinya remah kasar agak merata sebagai kuliatas taraf ketiga dari standar kualitas yang diharapkan peneliti.

\section{Uji Daya Terima Konsumen}

Penilaian organoleptik hedonik (tingkat kesukaan) terhadap roti tawar substitusi tepung beras hitam dengan persentase yang berbeda-beda dilakukan untuk mengetahui tingkat penerimaan konsumen terhadap produk roti tawar tersebut.

Aspek Volume

Hasil uji organoleptik aspek volume roti tawar substitusi tepung beras hitam dengan persentase tepung beras hitam $10 \%$ (A), 20\% (B), dan 30\% (C) terhadap 25 panelis tidak terlatih adalah sebagai berikut: 


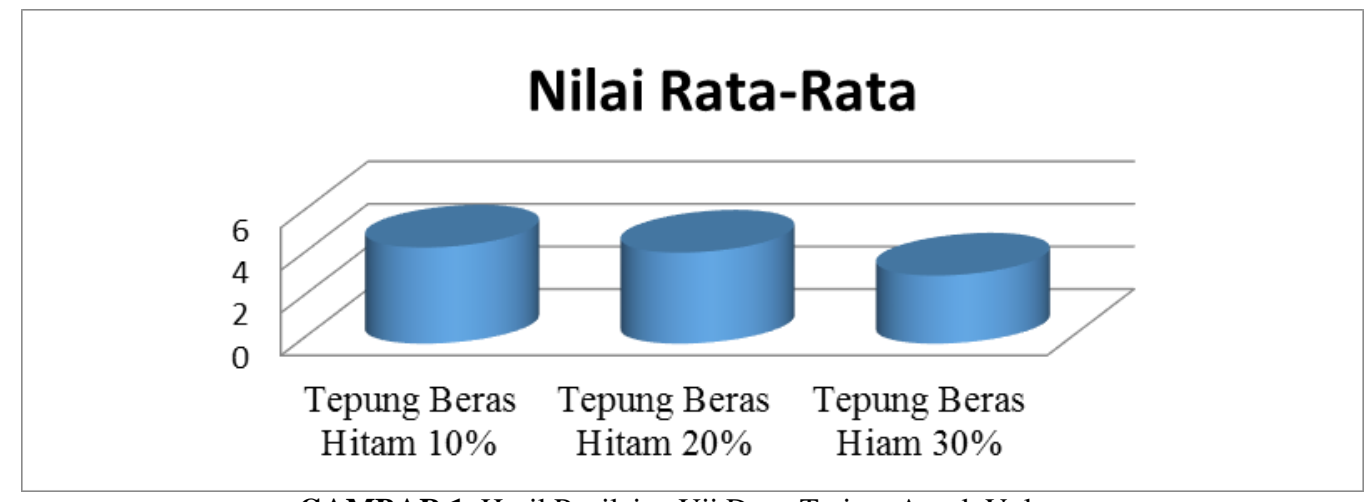

GAMBAR 1. Hasil Penilaian Uji Daya Terima Aspek Volume

Hasil penelitian dalam aspek volume berskala kategori yang diujikan pada 25 orang panelis tidak terlatih terhadap roti tawar substitusi tepung beras hitam, diketahui bahwa formula substitusi tepung beras hitam $10 \%$ memperoleh nilai rata-rata 4.52 yang menunjukkan kategori penilaian sangat suka. Pada persentase substitusi tepung beras hitam 20\% memperoleh nilai rata-rata 4.28 yang menunjukkan kategori penilaian suka. Pada persentase substitusi tepung beras hitam 30\% mendapatkan nilai rata-rata sebesar 3.2 yang menunjukkan kategori penilaian agak suka. Secara keseluruhan pada aspek rasa, produk yang paling disukai oleh panelis adalah roti tawar susbstitusi tepung beras hitam dengan persentase 10\% dengan nilai rata-rata yang diperoleh yaitu sebesar 4.52.

Aspek Warna Bagian Luar atau Kerak Kulit

Di bawah ini adalah hasil uji organoleptik aspek warna bagian luar roti tawar substitusi tepung beras hitam dengan persentase 10\% (A), 20\% (B), dan 30\% (C) terhadap 25 panelis tidak terlatih, antara lain:

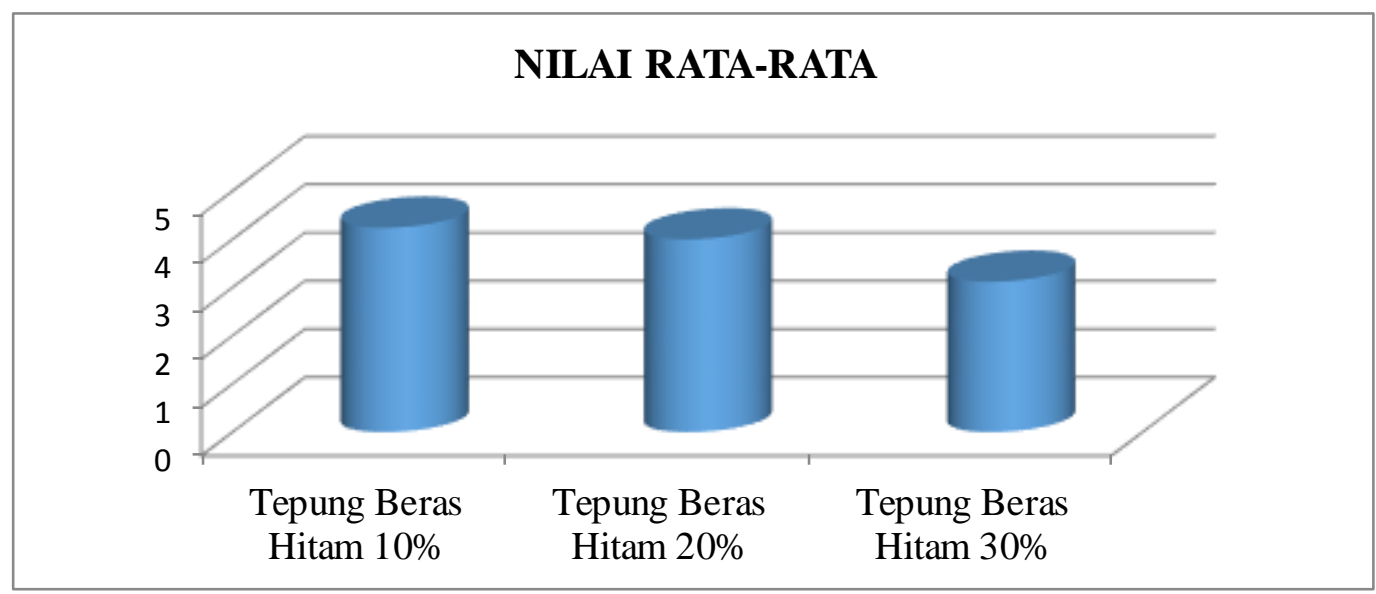

GAMBAR 2. Hasil Penilaian Uji Daya Terima Aspek Warna Bagian Luar / Kerak Kulit

Hasil penelitian uji organoleptik dalam aspek warna bagian luar roti tawar substitusi tepung beras hitam, diperoleh data yang menunjukkan pada formula substitusi tepung beras hitam 10\% memperoleh nilai rata-rata 4.24 yang menunjukkan kategori penilaian suka. Pada persentase substitusi tepung beras hitam $20 \%$ memperoleh nilai rata-rata 4.0 yang menunjukkan kategori penilaian suka. Pada persentase substitusi tepung beras hitam 30\% mendapatkan nilai rata-rata sebesar 3.12 yang menunjukkan kategori penilaian agak suka. Pada aspek warna bagian luar roti tawar substitusi tepung beras hitam 10\% merupakan produk yang paling disukai oleh konsumen. 
Aspek Remah atau Pori-Pori

Pada aspek remah atau pori-pori, hasil uji organoleptik kepada 25 panelis diperoleh hasil sebagai berikut:

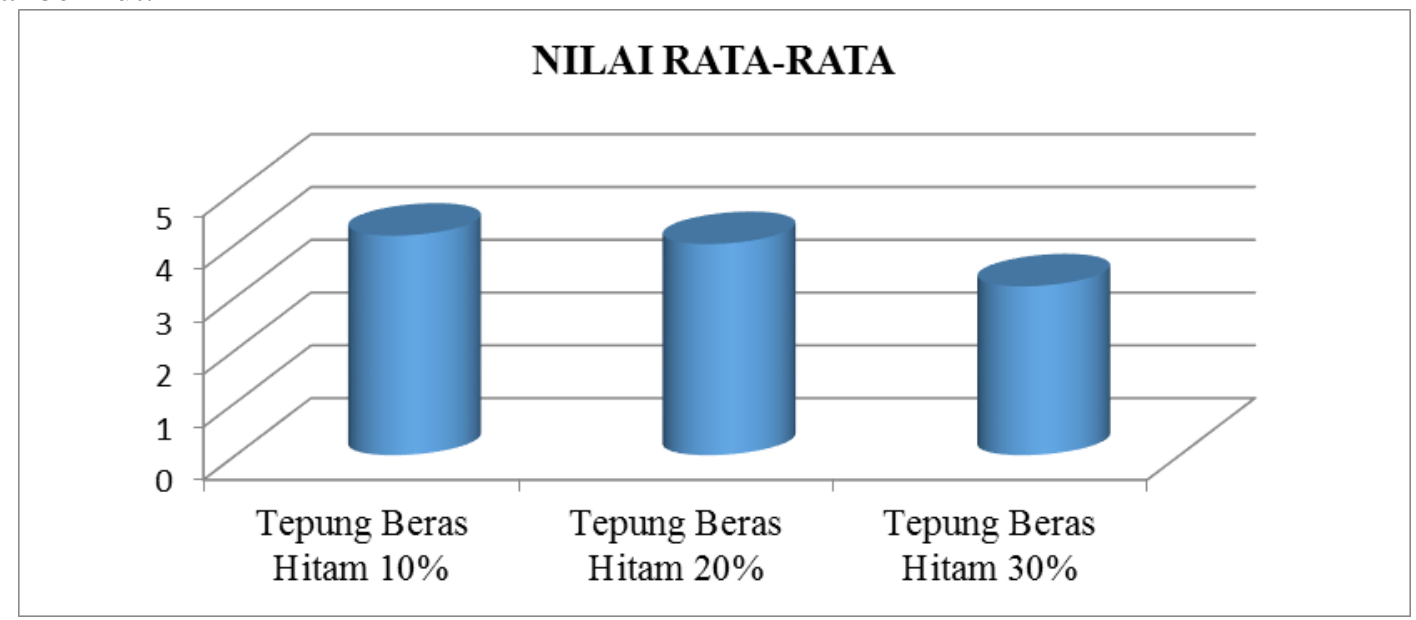

GAMBAR 3. Hasil Penilaian Uji Daya Terima Aspek Remah atau Pori-Pori

Pada aspek remah/pori-pori, hasil uji organoleptik pada panelis diperoleh data bahwa pada roti tawar substitusi tepung beras hitam sebesar $10 \%$ memperoleh nilai rata-rata 4.16 yang menunjukkan kategori penilaian suka. Pada roti tawar substitusi tepung beras hitam persentase $20 \%$ memperoleh nilai rata-rata 4.0 yang menunjukkan kategori penilaian suka. Pada roti tawar substitusi tepung beras hitam persentase mendapatkan nilai rata-rata sebesar 3.2 yang menunjukkan kategori penilaian agak suka.

\section{Aspek Warna Remah Bagian Dalam}

Pada aspek warna remah, data yang didapatkan dari hasil uji organoleptik kepada 25 panelis dapat dilihat pada gambar dibawah ini:

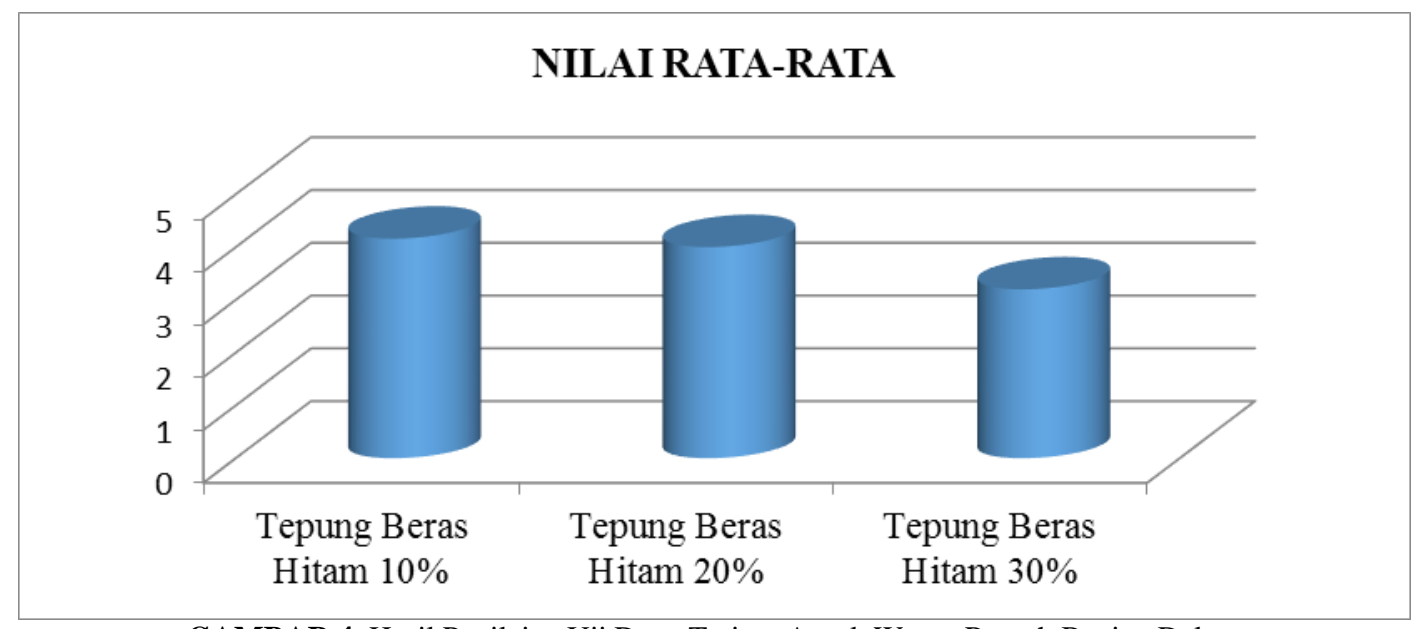

GAMBAR 4. Hasil Penilaian Uji Daya Terima Aspek Warna Remah Bagian Dalam

Pada aspek warna remah, berdasarkan hasil uji organoleptik diperoleh data bahwa pada substitusi tepung beras hitam dalam pembuatan roti tawar dengan persentase $10 \%$ menunjukkan nilai rata-rata yang didapatkan sebesar 4.12 yang menunjukkan katagori suka. Pada substitusi tepung beras hitam dalam pembuatan roti tawar dengan persentase $20 \%$ diperoleh nilai rata-rata sebesar 3.92 yang menunjukkan katagori suka. Sedangkan pada substitusi tepung beras hitam dalam pembuatan roti tawar dengan persentase $20 \%$ nilai rata-rata yang didapatkan sebesar 3.08 yang menunjukkan 
katagori agak suka. Produk yang paling disukai oleh panelis adalah roti tawar substitusi tepung beras hitam dengan persentase $10 \%$.

\section{Aspek Aroma}

Berikut adalah hasil penilaian organoleptik roti tawar substitusi tepung beras hitam dengan persentase $10 \%, 20 \%$, dan $30 \%$ yang diperoleh dari 25 panelis:

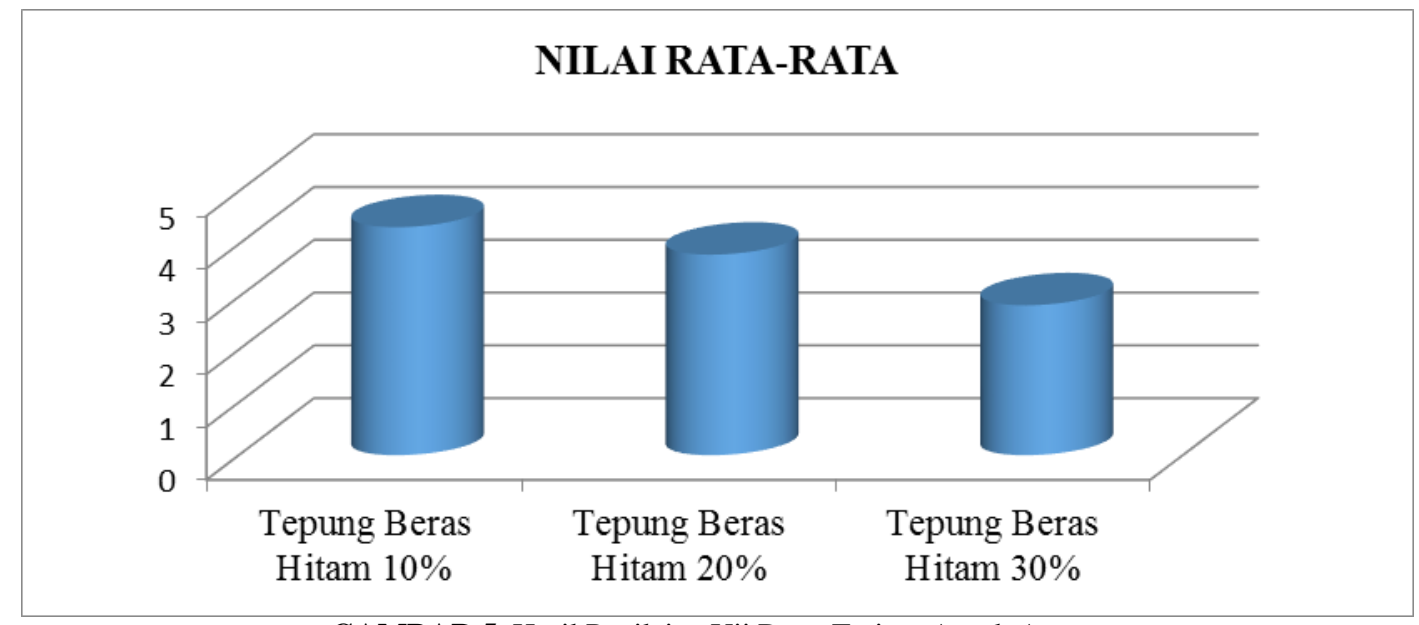

GAMBAR 5. Hasil Penilaian Uji Daya Terima Aspek Aroma

Pada aspek aroma, hasil penilaian organoleptik pada substitusi tepung beras hitam dalam pembuatan roti tawar dengan persentase $10 \%$ dan $20 \%$ masing-masing memperoleh nilai rata-rata sebesar 4.32 dan 3.8 yang menunjukkan katagori suka. Pada persentase substitusi tepung beras hitam dalam pembuatan roti tawar sebesar $30 \%$ nilai rata-rata yang didapatkan sebesar 2.84 yang menunjukkan skala penilaian agak suka.

\section{Aspek Rasa}

Hasil penilaian uji daya terima kepada 25 panelis terhadap roti tawar substitusi tepung beras hitam dengan persentase yang berbeda-beda dapat dilihat pada gambar berikut ini:

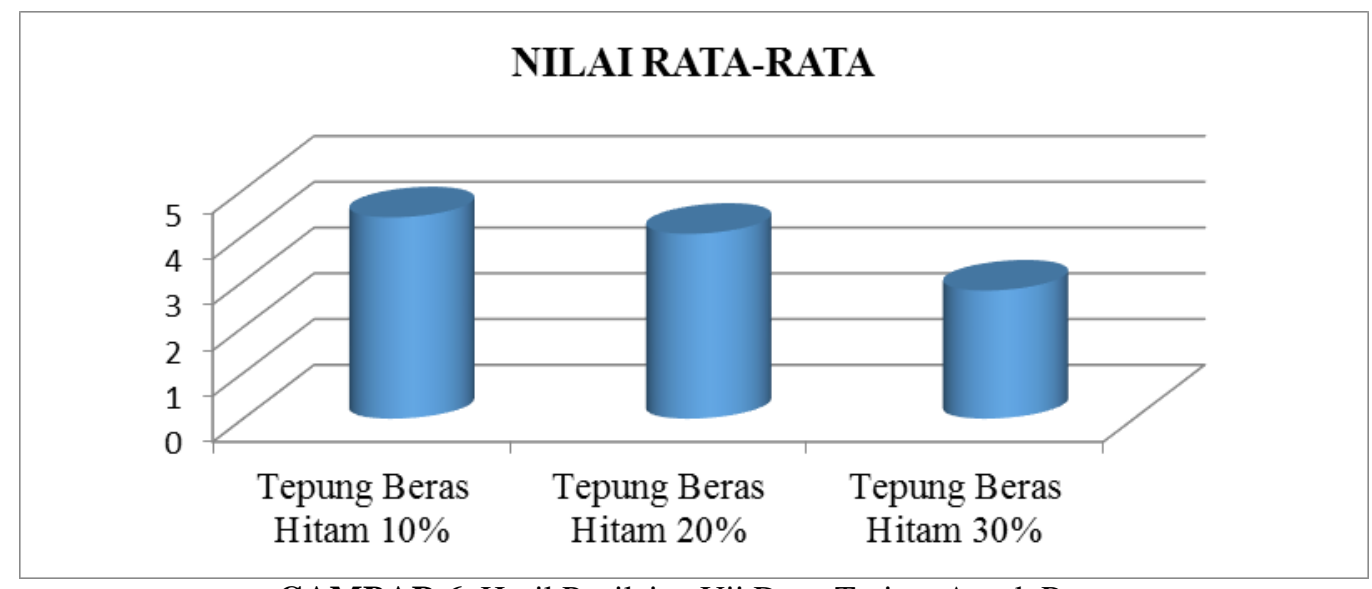

GAMBAR 6. Hasil Penilaian Uji Daya Terima Aspek Rasa

Pada roti tawar substitusi tepung beras hitam sebesar 10\% memperoleh nilai mean sebesar 4.4 yang menunjukkan skala katagori suka. Pada roti tawar substitusi tepung beras hitam sebesar $20 \%$ memperoleh nilai mean sebesar 4.04 yang menunjukkan skala katagori suka. Sedangkan pada roti tawar substitusi tepung beras hitam sebesar 30\% memperoleh nilai mean sebesar 3.0 yang menunjukkan skala katagori agak suka. 
Aspek Tekstur Remah

Berdasarkan hasil uji organoleptik terhadap aspek tekstur remah roti tawar substitusi tepung beras hitam, diperoleh data sebagai berikut:

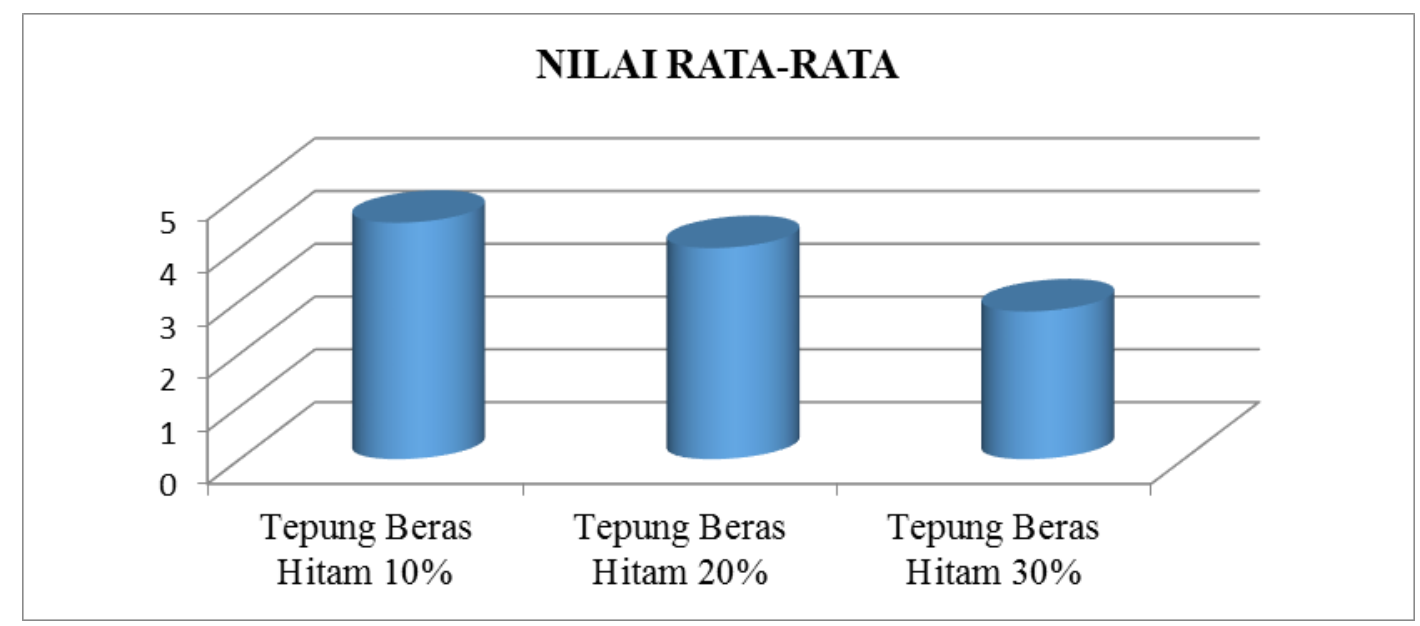

Grafik 7. Hasil Penilaian Uji Daya Terima Aspek Tekstur Remah

Hasil uji organoleptik pada aspek tekstur remah di persentase substitusi tepung beras hitam sebesar $10 \%$ memperoleh mean sebesar 4,48 yang menunjukkan kategori suka. Pada persentase tepung beras hitam $20 \%$ mendapatkan mean sebesar 4.0 yang menunjukkan kategori penilaian suka. Pada persentase substitusi tepung beras hitam sebesar 30\%, diperoleh mean sebesar 2.80 yang menunjukkan kategori penilaian agak suka.

Data yang diperoleh dari hasil uji organoleptik hedonik (kesukaan) dilanjutkan dengan pengujian hipotesis untuk membuktikan apakah terdapat ada atau tidaknya pengaruh terhadap beberapa aspek yang diujikan dengan menggunakan uji friedman pada taraf signifikansi $\alpha=0,05$. Hasil analisis uji hipotesis meliputi aspek eksternal (volume dan warna bagian luar), dan aspek internal (remah atau pori-pori, warna bagain dalam atau remahan, aroma, rasa dan tekstur) roti tawar substitusi tepung beras hitam dengan persentase 10\%, 20\%, dan 30\%.

Berdasarkan hasil uji hipotesis disimpulkan bahwa terdapat pengaruh substitusi tepung beras hitam pada pembuatan roti tawar terhadap daya terima konsumen pada seluruh aspek yang dinilai meliputi volume, warna kulit bagian luar, remah/pori-pori, warna bagian dalam, aroma, rasa dan tekstur.

Pada aspek volume, disimpulkan bahwa terdapat pengaruh pada aspek volume roti tawar substitusi tepung beras hitam dengan persentase 10\%, 20\% dan 30\%. Hal tepung beras hitam tidak mengandung gluten, sehingga semakin banyak substitute tepung beras hitam pada pembuatan roti tawar, produk roti tawar akan semakin kecil. Hal ini disebabkan tepung beras hitam tidak mengandung gluten, sehingga semakin banyak tepung terigu protein tinggi yang disubstitusikan dengan tepung beras hitam volume roti tawar yang dihasilkan akan semakin kecil. Hal ini sejalan dengan penelitian Sarofa, dkk (2017) menyatakan bahwa semakin banyak persentase tepung beras hitam maka semakin sedikit kandungan tepung terigu yang terdapat dalam adonan roti sehingga volume roti semakin kecil. Menurut Borla, dkk (2004) dalam penelitiannya juga menyatakan bahwa penambahan gluten pada tepung terigu dapat meningkatkan pengembangan roti tawar. Gluten sendiri berfungsi sebagai kerangka dasar roti (Mudjajanto dan Yulianti, 2013).

Hasil uji hipotesis menunjukkan bahwa terdapat pengaruh substitusi tepung beras hitam terhadap aspek warna bagian luar roti tawar. Warna kulit bagian luar dipengaruhi oleh bahan-bahan 
yang digunakan pada proses pembuatannya, salah satunya adalah jenis tepung yang digunakan. Pada penelitian ini tepung terigu yang digunakan disubstitusikan dengan tepung beras hitam yang memiliki kadar protein lebih rendah daripada tepung terigu. Sedangkan, warna bagian luar pada roti dihasilkan karena adanya proses karamelisasi pada proses pembakaran roti dengan suhu oven yang digunakan (Suhardjito, 2006). Astuti (2015) juga menyatakan bahwa penggunaan suhu pengovenan dapat mempengaruhi warna kulit luar roti yang dihasilkan, karena suhu oven yang terlalu tinggi menyebabkan warna kulit luar roti menjadi terlalu gelap dan sebaliknya suhu oven yang terlalu rendah menyebabkan warna kulit luar roti menjadi pucat.

Pada aspek remah atau pori-pori, hasil uji hipotesis menunjukkan terdapat pengaruh substitusi tepung beras hitam pada pembuatan roti tawar. Hal ini disebabkan tepung beras hitam memiliki kadar protein lebih rendah dari terigu, sehingga semakin banyak substitusi tepung beras hitam kemampuan protein menangkap gas akan semakin berkurang, produk akan menghasilkan pori-pori yang semakin besar. Hal ini sejalan dengan penelitian Sarofa dkk (2017) yang menyatakan bahwa meningkatnya keseragaman pori pada roti berhubungan dengan jumlah gas yang diperangkap oleh protein selama fermentasi sehingga keseragaman pori akan bertambah besar pada substitusi tepung beras yang semakin banyak.

Terdapat pengaruh substitusi tepung beras hitam terhadap aspek warna bagian dalam pada pembuatan roti tawar dikarenakan tepung terigu berwarna putih sedangkan tepung beras hitam memiliki karakteristik abu kehitaman, sehingga hasil akhir substitusi tepung beras hitam tidak sama dengan roti tawar pada umumnya. Hal ini sejalan dengan penelitian Hidayat dkk (2019) yang menyatakan bahwa semakin tinggi substitusi terigu dengan tepung beras hitam maka warna bakpao yang dihasilkan akan semakin kehitaman. Warna hitam tersebut diakibatkan oleh kandungan antosianin dalam beras hitam.

Pada aspek aroma dan rasa, hasil uji hipotesis menunjukkan terdapat pengaruh substitusi tepung beras hitam pada pembuatan roti tawar, hal ini disebabkan tepung terigu memiliki aroma dan rasa yang netral sedangkan tepung beras hitam yang memiliki aroma dan rasa yang kuat khas beras hitam. Pada pengujian lanjutan, yaitu uji Tuckey hasil yang diperoleh menunjukkan bahwa pada aspek aroma dan rasa roti tawar paling disukai oleh konsumen adalah roti tawar substitusi tepung beras hitam 10\% dan 20\%. Hal ini disebabkan semakin banyak substitusi tepung beras hitam, maka roti tawar yang dihasilkan memiliki aroma dan rasa khas beras hitam yang semakin kuat dan mempengaruhi tingkat kesukaan konsumen. Hal ini sejalan dengan penelitian Pusama dkk (2018) yang menunjukkan semakin tinggi penggunaan tepung ampas kepala yang digunakan pada roti tawar, menyebabkan tingkat kesukaan konsumen menurun karena roti tawar yang dihasilkan semakin memiliki rasa dan aroma kelapa.

Berdasarkan hasil uji Friedman disimpulkan bahwa terdapat pengaruh substitusi tepung beras hitam terhadap aspek tekstur remah roti tawar karena substitusi tepung beras hitam yang semakin tinggi akan menghasilkan tekstur remah yang semakin padat dan mempengaruhi kesukaan konsumen. Hal ini sejalan dengan penelitian Hidayat, dkk (2019) yang menyatakan bahwa semakin banyak pengunaan tepung beras hitam yang digunakan dalam pembuatan bakpao menyebakan mengandung kadar gluten yang semakin sedikit sehingga tekstur bakpao menjadi lebih padat.

\section{KESIMPULAN}

Hasil pengujian hipotesis dengan menggunakan Uji Friedman pada uji daya terima roti tawar substitusi tepung beras hitam dengan persentase 10\%,20\%, dan 30\% menunjukkan bahawa terdapat pengaruh pada semua aspek yang dinilai meliputi aspek volume, warna bagian luar / kerak kulit, remah/pori-pori, warna remah, aroma, rasa, dan tekstur remah. Setelah dilanjutkan dengan uji tuckey, diperoleh substitusi tepung beras hitam 10\% dan 20\% adalah produk yang lebih disukai oleh 
konsumen. Sehubungan dengan pengoptimalan penggunaan beras hitam serta untuk memasimalkan kandungan serat pangan dan indek glikemik pada produk roti tawar yang dihasilkan, maka produk yang direkomendasikan untuk diproduksi atau dikembangkan dalam bidang usaha pada penelitian ini adalah produk dengan formula substitusi tepung beras hitam sebanyak $20 \%$.

\section{SARAN}

Berdasarkan hasil penelitian ini yang menunjukan bahhwa produk roti tawar substitusi tepung beras hitam dapat diterima oleh masyarakat, sehingga perlu dilakukan penelitian lanjutan untuk mengetahui mengenai nilai gizi yang terkandung pada roti tawar substitusi tepung beras hitam dan umur daya simpan produk roti tawar substitusi tepung beras hitam.

\section{REFERENSI}

Alsuhendra \& Ridawati. 2008. Perinsip Zat Gizi Dan penilaian Organoleptik Bahan makanan. Jakarta: UNJ Press.

Adiluhung, W.D., dan Sutrisno A. 2018. Pengaruh Konsentrasi Glukomannan dan Waktu Proofing Terhadap Karakteristik Tekstur dan Organoleptik Roti Tawar Beras (Oryza sativa) Bebas Gluten. Jurnal Pangan dan Argroindustri Vol.6 No.4:26-37. Universitas Brawijaya Malang.

Anggraeno, Yudhitya (dkk). 2015. Karakteristik Roti Tawar Dengan Substitusi Tepung Gayam. Jurnal: Teknologi Hasil Pertanian Universitas Jember.

Astawan, M.Wresdiyati. 2004. Diet Sehat dengan Makanan Berserat. Surakarta: Tiga Serangkai.

Astuti, Romiyatun Mijiling. 2015. Pengaruh Pengunaan Suhu pengovenan Terhadap Kualitas Roti Manis Dilihat dari Aspek Warna kulit, Rasa, Aroma, dan Tekstur.Vol 2 No.2. Jurnal PKK, Falkutas Teknik UNNERS.

Arifin A.S, Yuliana N.D, Rafi M. 2019. Aktivitas Antioksidan pada Beras Berpigmen dan Dampaknya terhadap Kesehatan. Jurnal: Departemen Ilmu dan Teknologi Pangan, Fakultas Teknologi Pertanian, Institut Pertanian Bogor.

Artanty, Marita Anggiet. 2015. Eksperimen Pembuatan Roll Cake Bahan Dasar Tepung Beras Hitam (Oryza Sativa L.Indica) Substitusi Tepung Terigu. Skripsi: Tata Boga Universitas Negeri Semarang.

Azis, A., Izzati, M., Haryanti, S. 2015.Aktivitas Antioksidan dan Nilai Gizi dari Beberapa Jenis Beras dan Millet Sebagai Bahan Pangan Fungsional Indonesia. Jurnal Biologi: Universitas Diponegoro.

Bahalwan, Fatma dan Tim NCC. 2017. 35 Model Roti Yang Mudah \& Cantik Step by Step. Jakarta: PT Gramedia Pustaka Utama.

Balai Besar Penelitian Tanaman Padi (BBPADI) Kementerian Pertanian. 2019. Beras Hitam Tinggi Kandungan Antisianin dan Meningkatkan Sistem Kekebalan Tubuh. www.bbpadi.litbang.pertanian.go.id. Diakses 10 Maret 2020.

Borla, O.P., Moetta, E.L, Saiz, A.I., \& Fritz, R. (2004). Quality parameters and baking performance of commercial glueten flours.LWT-Food Scienceand Technology, Vol 37 (7): 723-729. doi.org/10.1016/j.lwt.2004.02.013

Dinas Pertanian. 2016. Beras Hitam. Diakses melalui https://distan.bulelengkab.go.id/artikel/berashitam-oryza-sativa-1-indica-97

Hidayat, R.R, Sugitha, I.I, dan Wiadnyani, A.A.I.I.S. 2019. Pengaruh Perbandingan Tepung Beras Hitam (Oryza Sativa L. Indica) dengan Terigu Terhadap Karakteristik Bakpao. Jurnal: Ilmu dan Teknologi Pangan Unud Kampus Bukit Jimbaran Bali.

Kementerian Kesehatan Republik Indonesia. 2018. Data Komposisi Pangan Indonesia Tepung Terigu dan Beras Hitam. Diakses melalui www.pangan.org

Kementrian Pertanian. 2018. Data Statistik Komsumsi Pangan. Diakses melalui http://epublikasi.setjen.pertanian.go.id/epublikasi/StatistikPertanian/2018/Konsumsi/Statistik Konsumsi_Pangan_Tahun_2018/files/assets/basic-html/page124.html. 
Kristamtini K., Taryono, Panjisakti B., Rudi H.M. VOL 33, NO 1. 2014. Beras Hitam Sumber Antosianin dan Prospeknya Sebagai Pangan Fungsional. Jurnal penelitian dan pengembangan pertanian.

Latifah, dkk. 2014. Penggunaan Tepung Beras Hitam Dan Gliserol monostearat pada pembuatan roti tawar (using of black rice flour and glycerol monostearate in making of white bread). Jurnal: UPN Veteran Jawa Timur.

Mudjajanto E.S dan Yulianti I.N. 2010. Membuat Aneka Roti. Jakarta: Penebar Swadaya.

Muhariati, Metty. 2008. Bahan Ajar Roti. Jakarta: Penerbit Universitas Indonesia.

Nimpuno, Diah. 2019. Roti Buatan Rumah Klasik dan Kekenian. Jakarta: PT Gramedia Pustaka Utama.

Nugraheni, M. 2014. Pewarna Alami: Sumber dan Aplikasinya Pada Makanan dan Kesehatan. Yogyakarta: Graha Ilmu.

Pusuma, Deni Antra (dkk). 2018. Karakteristik Roti Tawar Kaya Serat Yang Disubstitusi Menggunakan Tepung Ampas Kelapa. Jurnal: Agroteknologi. Universitas Jember.

Rauf, Rusdin dan Khasanah Tri Andini. 2019. Sifat Fisik dan Penerimaan Roti Tawar dari Tepung Komposit Tepung Terigu dan Singkong dengan Variasi Lama Pencampuran Adonan. Jurnal: Ilmu Gizi Universitas Muhamaddiyah.

Rezza, Mutiara. 2019. Pengaruh Substitusi Tepung Beras Hitam Pada Pembuatan Telur Gabus Terhadap Daya Terima Konsumen. Skripsi Sarjana Universitas Negeri Jakarta.

Roswaty, Aan. 2012. Resep Favorit Anak ala Resto Roti Tawar Untuk Bekal Sekolah. Jakarta: PT. Gramedia Pustaka Utama.

Sandjaja. 2009. Kamus Gizi Pelengkap: Kesehatan Keluarga. Jakarta: Penerbit Kompas.

Shobariah, Nur Laila. 2017. Pengaruh Substitusi Tepung Beras Dan Jagung (rice \& Corn) Pada Pembuatan Roti Tawar Terhadap Daya Terima Konsumen. Skripsi Sarjana Universitas Negeri Jakarta.

Sugiyono. 2014. Metode penelitian Kuantutatif, Kualitatif dan Kombinasi (Mixed Methodes). Ed ke5 Bandung: Alfabeta

Suhardjito, Y.B. 2006. Pastry dalam Perhotelan. Yogyakarta: Penerbit ANDI.

Suryana, Dayat. 2013. Cara Membuat Tepung: Tepung. CreateSpace Independent Publishing.

Utama, M. Z. H. 2019. Budidaya Padi Hitam dan Merah. Yogyakarta: Penerbit ANDI (Anggota IKAPI).

Wijayanti, Intan Wahyu. 2018. Pengaruh Substitusi Tepung Beras Hitam Terhadap Komposisi Proksimat dan Daya Terima Butter Cookies. Jurnal: Ilmu Gizi. Universitas Muhammdiyah Surakarta.

Wulandari, N.K.N., Ekawati, I.G.A.E., Putra, I.N.K., 2019. Pengaruh Perbandingan Semolina dan Tepung Beras Hitam Terhadap Karakteristik Pasta Fettucine Basah. Jurnal Ilmu dan Teknologi Pangan Unud.

Zuhriani, Frida. 2015. Kualitas Organoleptik Brownies Kukus dari Tepung Beras Hitam. Skripsi: Pendidikan Biologi. Universitas Muhammdiyah Surakarta.

Zulfi, Rizki Fawzan. 2017. Pengaruh Substitusi Tepung Beras Hitam Pada Pembuatan Rempeyek Kacang Tanah Terhadap Daya Terima Konsumen. Skripsi Sarjana Universitas Negeri Jakarta. 